and $\mathrm{S}$ atoms are listed in Table 1 . $^{*}$ Bond lengths, bond angles and selected torsion angles are given in Table 2. The $C(2)-C(3)$ bond of $1.346(5) \AA$ is comparable to the $\mathrm{C}=\mathrm{C}$ bond of $1.362(25) \AA$ in thiophenes (Allen, Kennard, Watson, Brammer, Orpen \& Taylor, 1987). The $\mathrm{S}(3)-\mathrm{C}(2)$ bond of 1.719 (4) $\AA$ is longer than the $\mathrm{C}=\mathrm{S}$ bond of $1.683(1) \AA$ in the substituted thione 4phenylthiazole-2 $(3 H)$-thione (Nalini \& Desiraju, 1989) and is comparable to the $S(1)-C(1)$ and $\mathrm{S}(2)-\mathrm{C}(1)$ bonds of 1.715 (4) and 1.710 (3) $\AA$ respectively, but is significantly shorter than the $\mathrm{S}(1)-\mathrm{C}(2)$ and $\mathrm{S}(2)-\mathrm{C}(3)$ bonds of $1.764(3)$ and $1.753(3) \AA$ respectively. The short $S(3)-C(2)$ bond can be viewed as a single bond with the $\mathrm{S}$ atom carrying a negative charge so that $\mathrm{C}(2)$ is positive relative to $\mathrm{S}(3)$. The comparable and short $\mathrm{S}(1)-\mathrm{C}(1)$ and $\mathrm{S}(2)-\mathrm{C}(1)$ bonds can be viewed as a positive charge in the pentatomic ring close to $C(1)$ so that $C(1)$ is positive relative to the $S(1)$ and $S(2)$ atoms. The pentatomic ring system is nearly planar and the torsion angles involving the five ring atoms are close to 0 and $180^{\circ}$. All the features of the pentatomic

\footnotetext{
* Lists of structure factors, anisotropic thermal parameters, $\mathrm{H}$-atom parameters, least-squares planes and a complete list of bonding interactions have been deposited with the British Library Document Supply Centre as Supplementary Publication No. SUP 54586 (22 pp.). Copies may be obtained through The Technical Editor, International Union of Crystallography, 5 Abbey Square, Chester $\mathrm{CH} 12 \mathrm{HU}$, England.
}

heterocyclic system in this compound agree very well with those in 5-methyl-2-piperidino-1,3-dithiolium-4thiolate (Cheung et al., 1991). The $\mathrm{C}(1)-\mathrm{N}$ bridging distance between the two ring systems is 1.321 (4) $\AA$. The morpholinyl ring has a chair conformation with $\mathrm{N}$ and $\mathrm{O}$ deviating $-0.560(2)$ and $+0.670(2) \AA$ respectively from the plane through $\mathrm{C}(7), \mathrm{C}(8), \mathrm{C}(9)$ and $\mathrm{C}(10)$. The $\mathrm{C}_{s p^{3}}-\mathrm{N}_{s p^{3}}$ bonds are $1.468(4)$ and 1.472 (4) $\AA$, the $C_{s p^{3}}-C_{s p^{3}}$ bonds are 1.511 (4) and 1.512 (4) $\AA$, while the $\mathrm{C}_{s p^{3}}-\mathrm{O}$ bonds are $1.432(4)$ and 1.419 (4) $\AA$, and all six bond angles are close to $109.5^{\circ}$

\section{References}

Allen, F. H., Kennard, O., Watson, D. G., Brammer, L., OrPen, G. \& TAYlor, R. (1987). J. Chem. Soc. Perkin Trans. 2, pp. S1-S19.

Beurskens, P. T., Bosman, W. P., Doesburg, H. M., Gould, R. O., van den Hark, Th. E. M., Prick, P. A. J., NoOrdik, J. H., BEuRSKens, M. \& SmITH, J. M. M. (1984). DIRDIF. Tech. Rep. 1984/1. Crystallography Laboratory, Toernooiveld, 6525 ED Nijmegen, The Netherlands.

Cheung, K. K., Galembeck, S., Miller, J., De Oliveira, M. B., Pereira, A. B. \& Simas, A. M. (1991). Acta Cryst. C47, 2630-2632.

Enraf-Nonius (1985). Structure Determination Package. EnrafNonius, Delft, The Netherlands.

JOHNSON, C. K. (1976). ORTEPII. Report ORNL-5138. Oak Ridge National Laboratory, Tennessee, USA.

Nalini, V. \& Desiraju, G. R. (1989). Acta Cryst. C45, 15251527.

Acta Cryst. (1992). C48, 525-527

\title{
Structure of an Intermediate Methylated Product in the Synthesis of Drimanes
}

\author{
By Kalyan Das and U. C. Sinha* \\ Department of Physics, Indian Institute of Technology, Bombay-400 076, India \\ S. R. Desai And S. V. Bhat \\ Department of Chemistry, Indian Institute of Technology, Bombay-400 076, India \\ and S. S. Tavale and V. G. Puranaik \\ Physical and Structural Chemistry Division, National Chemical Laboratory, Pune-411 008, India
}

(Received 14 February 1991; accepted 14 August 1991)

\begin{abstract}
.
5-Methoxymethyl-1,1,4a-trimethyl6-[(phenylthio)methyl]-1,5,8,8a-tetrahydro-4(4aH)naphthalenone, $\mathrm{C}_{22} \mathrm{H}_{28} \mathrm{O}_{2} \mathrm{~S}, \quad$ m.p. $=382 \mathrm{~K}, \quad M_{r}=$ 356.53, monoclinic, $P 2_{1} / c, \quad a=11.810(1), \quad b=$ $8.929(2), \quad c=18.716(1) \AA$ À $, \quad \beta=92.773(8)^{\circ}, \quad V=$
\end{abstract}

* To whom correspondence should be addressed.

0108-2701/92/030525-03\$03.00
$1971.32 \AA^{3}, Z=4, D_{x}=1.201 \mathrm{Mg} \mathrm{m}^{-3}, \lambda(\mathrm{Mo} \mathrm{K \alpha})$ $=0.71069 \AA, \mu($ Mo $K \alpha)=0.137 \mathrm{~mm}^{-1}, \quad F(000)=$ $768, T=291 \mathrm{~K}$, final $R=0.055, w R=0.074$ using 2674 reflections. The bicyclic skeleton of the molecule is cis fused. An intermolecular $\mathrm{C}-\mathrm{H} \cdots \mathrm{O}$ interaction $\left[\mathrm{C}(20)-\mathrm{H}(20) \cdots \mathrm{O}\left(1^{\prime}\right) \quad 3.306(3) \AA\right]$ was observed.

(C) 1992 International Union of Crystallography 
Introduction. Drimanes, both cis (Hirai, Nozoe \& Tsuda, 1967) and trans (Kubo, Lee, Pettei, Pilikiewicz \& Nakanishi, 1976; Ma \& Kubo, 1977) fused, are known to be biologically active naturally occurring compounds. In an attempt to develop a new Diels-Alder strategy towards the synthesis of drimanes, the angular methylation of a crucial intermediate was of interest. The stereochemistry of the ring fusion in the methylated product could not be established unambiguously from spectroscopic studies. In order to assign the detailed stereochemistry, structural confirmation was essential. As the above synthesized angular methylated product was a liquid, an SPh group was introduced which yielded the title compound (1) as a crystalline product. The crystal structure was analyzed using $\mathrm{X}$-ray diffraction techniques.

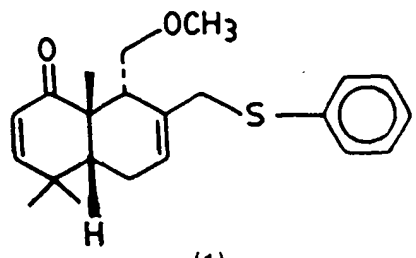

(1)

Experimental. Transparent crystals were obtained from a petroleum ether and chloroform solution of the title compound (Gore, Desai, Moyelvaganan, Padmakumar \& Bhat, 1991). Intensity data were collected from a crystal, $0.13 \times 0.27 \times 0.34 \mathrm{~mm}$, using an Enraf-Nonius CAD-4 diffractometer with graphite-monochromated Mo $K \alpha \quad(\lambda=0.71069 \AA)$ radiation. The cell constants were refined using 25 reflections in the range $9 \leq \theta \leq 16^{\circ}$. A total of 2890 unique reflections $\left(R_{\text {int }}=0.009\right)$ were scanned. $\omega / 2 \theta$ mode, in the range $0 \leq \theta \leq 23.5^{\circ}$ with $h_{\max }=13, k_{\max }$ $=10$ and $l_{\min / \max }=\mp 21$. Three standard reflections checked at every $3600 \mathrm{~s}$ interval indicated no significant variation in intensity. Data were corrected for $\mathrm{Lp}$ factors, neglecting the effects due to absorption and extinction. The structure was determined by the multisolution direct-methods package MULTAN88 (Debaerdemaeker, Germain, Main, Refaat, Tate \& Woolfson, 1988) using the Sayre equation tangent formula for phase refinements. With an assigned weight of 0.60 for negative quartets, all non-H atoms were located from the $E$ map corresponding to the seventh phase set (RESID = 17.27, $\mathrm{CFOM}=2.758$ ). $\mathrm{H}$ atoms were located from difference Fourier maps. The structure refinement was by the least-squares method based on $F$ values. In the final refinement, non- $\mathrm{H}$ atoms were refined anisotropically and $\mathbf{H}$ atoms isotropically; 338 parameters refined using 2674 observed reflections with $F_{o} \geq 3.0 \sigma\left(\left|F_{o}\right|\right)$. Final $R=0.055$ and $w R=$
Table 1. Atomic coordinates $\left(\times 10^{5}\right.$ for $\mathrm{S} ; \times 10^{4}$ for remaining non- $\mathrm{H}$ atoms) and equivalent isotropic temperature factors $\left(\AA^{2} \times 10^{3}\right)$ with e.s.d.'s in parentheses

$$
U_{\mathrm{eq}}=\frac{1}{3} \sum_{i} \sum_{j} U_{i j} a_{i}^{*} a_{j}^{*}\left(\mathbf{a}_{i} \cdot \mathbf{a}_{j}\right)
$$

$\begin{array}{lcccc} & x & y & z & U_{\text {eq }} \\ \mathrm{S} & 59211(6) & 25838(8) & 93205(4) & 48(1) \\ \mathrm{O}(1) & 2312(2) & 4024(2) & 7047(1) & 67(2) \\ \mathrm{O}(2) & 4484(2) & 2243(2) & 6774(1) & 48(2) \\ \mathrm{C}(1) & 1744(2) & -448(3) & 7623(2) & 45(3) \\ \mathrm{C}(2) & 1725(2) & 143(4) & 6876(2) & 55(3) \\ \mathrm{C}(3) & 1944(3) & 1557(4) & 6689(2) & 56(3) \\ \mathrm{C}(4) & 2323(2) & 2704(3) & 7203(2) & 45(3) \\ \mathrm{C}(4 \mathrm{a}) & 2712(2) & 2171(3) & 7953(1) & 35(2) \\ \mathrm{C}(5) & 4010(2) & 1799(3) & 7978(1) & 33(2) \\ \mathrm{C}(6) & 4347(2) & 900(3) & 8637(1) & 37(2) \\ \mathrm{C}(7) & 3603(2) & 234(3) & 9039(1) & 44(2) \\ \mathrm{C}(8 \mathrm{a}) & 1952(2) & 841(3) & 8174(1) & 39(2) \\ \mathrm{C}(8) & 2341(2) & 292(4) & 8914(1) & 47(3) \\ \mathrm{C}(9) & 2574(3) & -1783(3) & 7693(2) & 58(4) \\ \mathrm{C}(10) & 550(3) & -1100(5) & 7734(3) & 73(4) \\ \mathrm{C}(11) & 2556(3) & 3464(3) & 8485(2) & 53(3) \\ \mathrm{C}(12) & 4478(2) & 1112(3) & 7307(1) & 39(2) \\ \mathrm{C}(13) & 4796(4) & 1680(4) & 6110(2) & 62(4) \\ \mathrm{C}(14) & 5590(2) & 846(3) & 8859(2) & 43(3) \\ \mathrm{C}(15) & 7386(2) & 2485(3) & 9549(1) & 38(2) \\ \mathrm{C}(16) & 7805(3) & 3552(3) & 10037(2) & 51(3) \\ \mathrm{C}(17) & 8953(3) & 3559(4) & 10241(2) & 67(4) \\ \mathrm{C}(18) & 9665(3) & 2536(4) & 9964(2) & 70(4) \\ \mathrm{C}(19) & 9257(3) & 1477(4) & 9484(2) & 58(3) \\ \mathrm{C}(20) & 8116(2) & 1442(3) & 9276(1) & 45(3) \\ & & & & \end{array}$

0.074, where $w=1.000 /\left[\sigma^{2}(F)+0.0234 F^{2}\right],(\Delta / \sigma)_{\max }$ $=0.065$. In final difference $\operatorname{map}(\Delta \rho)_{\max }=0.269$ and $(\Delta \rho)_{\min }=-0.389 \mathrm{e} \AA^{-3}$. SHELX76 (Sheldrick, 1976) was used for the structure refinements and a CYBER-180 for all the computations. Scattering factors were those imbedded in SHELX76.

Discussion. The atomic coordinates for non- $\mathrm{H}$ atoms are listed in Table 1 and the bond distances along with the bond angles in Table 2.* Fig. 1 represents the perspective view of the molecule (Motherwell \& Clegg, 1978).

The bicyclic skeleton of the molecule is cis fused with torsion angle $\mathrm{C}(11)-\mathrm{C}(4 \mathrm{a})-\mathrm{C}(8 \mathrm{a})-\mathrm{H}(8 \mathrm{a})=$ $53.3(2)^{\circ}$. Ring $A$ has an approximate sofa conformation, with $C(4 a) 0.536$ (2) $\AA$ out of the least-squares plane [with maximum deviation \pm 0.075 (3) $\AA$ ] passing through the remaining five atoms. In ring $B$, the orientation of the $\mathrm{CH}_{2} \mathrm{OCH}_{3}$ group [attached to $\mathrm{C}(5)$ ] is opposite to the orientation of the methyl carbon, C(11), attached to C(4a). However, both $C(4 a)$ and $C(5)$ are on the same side, by -0.737 (2) and $-0.260(2) \AA$ respectively, of the mean plane passing through the atoms $\mathrm{C}(6), \mathrm{C}(7), \mathrm{C}(8)$ and $\mathrm{C}(8 \mathrm{a})$ [with maximum deviation 0.083 (3) $\AA$ from the

\footnotetext{
* Lists of structure factors, anisotropic thermal parameters, H-atom parameters and least-squares planes have been deposited with the British Library Document Supply Centre as Supplementary Publication No. SUP 54500 (17 pp.). Copies may be obtained through The Technical Editor, International Union of Crystallography, 5 Abbey Square, Chester CH1 2HU, England.
} 
Table 2. Bond distances $(\AA)$ and principal angles $\left({ }^{\circ}\right)$ with e.s.d.'s in parentheses

\begin{tabular}{|c|c|c|c|}
\hline$C(14)-s$ & $1.810(3)$ & $C(11)-C(4 a)$ & $1.541(4)$ \\
\hline$C(15)-S$ & $764(3)$ & $C(6)-C(5)$ & $1.508(3)$ \\
\hline $\mathrm{C}(4)-\mathrm{O}(1)$ & $214(3)$ & $C(12)-C(5)$ & $1.524(4)$ \\
\hline $\mathrm{C}(12)-\mathrm{O}(2)$ & 420 (3) & $C(7)-C(6)$ & $1.325(4)$ \\
\hline $\mathrm{C}(13)-O(2)$ & $406(4)$ & $C(14)-C(6)$ & 1.507 (4) \\
\hline$C(2)-C(1)$ & $493(4)$ & $C(8)-C(7)$ & $1.498(4)$ \\
\hline$C(8 a)-C(1)$ & $557(4)$ & $C(8)-C(8 a)$ & \multirow[t]{2}{*}{$1.520(4)$} \\
\hline$C(9)-C(1)$ & $545(4)$ & $C(16)-C(15)$ & \\
\hline$C(10)-C(1)$ & 549 (4) & $C(20)-C(15)$ & $1.383(4)$ \\
\hline$C(3)-C(2)$ & $339(5)$ & $C(17)-C(16)$ & $1.391(5)$ \\
\hline$C(4)-C(3)$ & $461(5)$ & $C(18)-C(17)$ & $1.361(5)$ \\
\hline$C(4 a)-C(4)$ & $532(4)$ & $C(19)-C(18)$ & $1.375(5)$ \\
\hline$C(5)-C(4 a)$ & $567(3)$ & $C(20)-C(19)$ & $1.384(4)$ \\
\hline$C(8 a)-C(4 a)$ & \multicolumn{3}{|c|}{$1.556(3)$} \\
\hline$C(15)-S-C(14)$ & $105.0(1)$ & $C(12)-C(5)-C(4 a)$ & $117.0(2)$ \\
\hline $\mathrm{C}(13)-\mathrm{O}(2)-\mathrm{C}(12)$ & $112.2(2)$ & $C(12)-C(5)-C(6)$ & $111.5(2)$ \\
\hline$C(8 a)-C(1)-C(2)$ & $110.7(2)$ & $C(7)-C(6)-C(5)$ & $123.1(2)$ \\
\hline$C(9)-C(1)-C(2)$ & $109.5(3)$ & $C(14)-C(6)-C(5)$ & $117.3(2)$ \\
\hline$C(9)-C(1)-C(8 a)$ & $115.7(2)$ & $C(14)-C(6)-C(7)$ & $119.5(2)$ \\
\hline$C(10)-C(1)-C(2)$ & $106.6(3)$ & $C(8)-C(7)-C(6)$ & $125.3(2)$ \\
\hline$C(10)-C(1)-C(8 a)$ & $107.7(2)$ & $C(4 a)-C(8 a)-C(1)$ & $117.6(2)$ \\
\hline$C(10)-C(1)-C(9)$ & $106.1(3)$ & $C(8)-C(8 a)-C(1)$ & $113.4(2)$ \\
\hline$C(3)-C(2)-C(1)$ & $125.8(3)$ & $C(8)-C(8 a)-C(4 a)$ & $109.6(2)$ \\
\hline$C(4)-C(3)-C(2)$ & 123.0 & $C(8 a)-C(8)-C(7)$ & $114.1(2)$ \\
\hline$C(3)-C(4)-O(1)$ & $121.5(3)$ & $C(5)-C(12)-O(2)$ & $107.9(2)$ \\
\hline$C(4 a)-C(4)-O(1)$ & $121.5(3)$ & $C(6)-C(14)-S$ & $106.8(2)$ \\
\hline$C(4 a)-C(4)-C(3)$ & $117.1(2)$ & $C(16)-C(15)-S$ & $115.9(2)$ \\
\hline$C(5)-C(4 a)-C(4)$ & $110.1(2)$ & $C(20)-C(15)-S$ & $124.5(2)$ \\
\hline$C(8 a)-C(4 a)-C(4)$ & $109.2(2)$ & $C(20)-C(15)-C(16)$ & $119.6(3)$ \\
\hline$C(8 a)-C(4 a)-C(5)$ & $114.0(2)$ & $C(17)-C(16)-C(15)$ & $119.5(3)$ \\
\hline$C(11)-C(4 a)-C(4)$ & $108.6(2)$ & $C(18)-C(17)-C(16)$ & $120.3(3)$ \\
\hline$C(11)-C(4 a)-C(5)$ & $106.7(2)$ & $C(19)-C(18)-C(17)$ & $120.4(3)$ \\
\hline$C(11)-C(4 a)-C(8 a)$ & $108.2(2)$ & $C(20)-C(19)-C(18)$ & $120.3(3)$ \\
\hline$C(6)-C(5)-C(4 a)$ & $110.9(2)$ & $C(19)-C(20)-C(15)$ & $119.8(3)$ \\
\hline
\end{tabular}

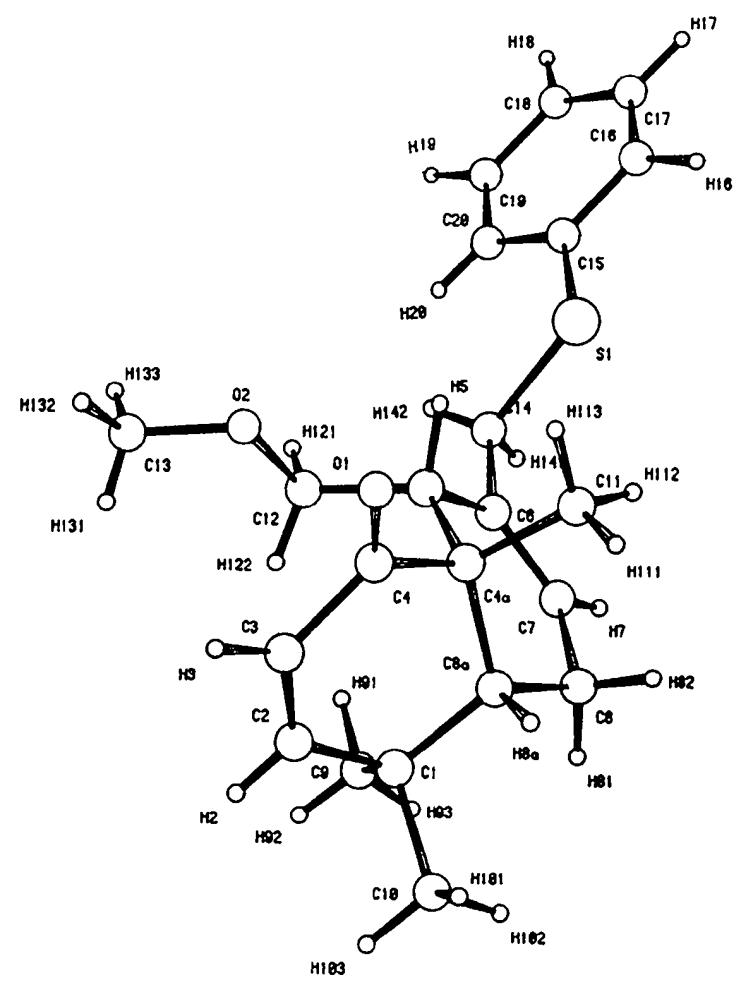

Fig. 1. Perspective view of the molecule.

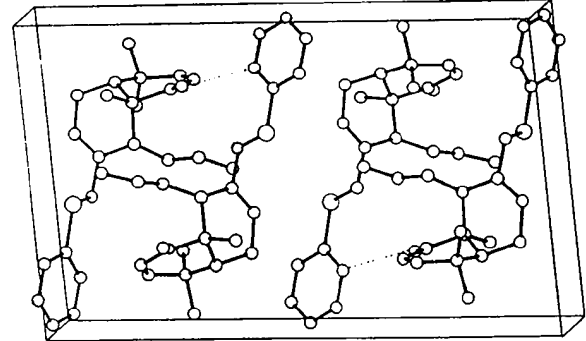

Fig. 2. Unit-cell packing diagram.

least-squares plane]. Ring $B$ is in a distorted halfchair conformation. The dihedral angle between the mean planes passing through rings $A$ and $B$ is $69.0(3)^{\circ}$. The atom $\mathrm{C}(14)$, to which the $\mathrm{SPh}$ group is attached, is in the plane [with deviation $0.023(2) \AA$ ] passing through ring $B$. For the $\mathrm{S}$ atom, $\mathrm{C}\left(s p^{3}\right)-\mathrm{S}$ and $\mathrm{C}\left(s p^{2}\right)-\mathrm{S}$ bonds are localized with respective bond lengths, $1.810(3)$ and $1.764(3) \AA$. The $\mathrm{C}\left(s p^{3}\right)-$ $\mathrm{C}\left(s p^{3}\right)$ bond lengths range from 1.461 (5) to 1.567 (3) with an average 1.525 (4) $\AA$. Remaining bond lengths and angles are close to normal values.

Fig. 2 shows the crystal packing diagram; the dotted lines indicate intermolecular $\mathrm{C}-\mathrm{H} \cdots \mathrm{O}$ interactions (Taylor \& Kennard, 1982; Das, Sinha, Narkhede \& Manisekharan, 1990). The distance between $\mathrm{C}(20)$ and $\mathrm{O}\left(\mathrm{1}^{\mathrm{i}}\right)\left[(\mathrm{i}) 1-x, \frac{1}{2}+y, \frac{3}{2}-z\right]$ is $3.306(3)$ with $\mathrm{H}(20) \cdots \mathrm{O}\left(1^{\mathrm{i}}\right)$ distance $2.41(5) \AA$ and $\mathrm{C}-\mathrm{H} \cdots \mathrm{O}$ angle $169.9(10)^{\circ}$. The closest intermolecular $\mathrm{C} \cdots \mathrm{S}$ distance is between $\mathrm{C}(13)$ and $\mathrm{S}^{\mathrm{i}}$, $3.720(2) \AA$, with the $\mathrm{C}(13)-\mathrm{H}(132) \cdots \mathrm{S}$ angle $119.2(8)^{\circ}$.

The authors acknowledge help from the National Chemical Laboratory, Pune, for extending the CAD-4 facility for intensity data.

\section{References}

Das, K., Sinha, U. C., Narkhede, D. D. \& Manisekharan, T. (1990). Acta Cryst. C46, 1888-1890.

Debaerdemaeker, T., Germain, G., Main, P., Refaat, L. S., TATE, C. \& WoOlfSON, M. M. (1988). MULTAN88. A System of Computer Programs for the Automatic Solution of Crystal Structures from X-ray Diffraction Data. Univ. of York, England.

Gore, V. K., Desai, S. R., Moyelvaganan, T., Padmakumar, R. \& BHAT, S. V. (1991). Tetrahedron Lett. Submitted.

Hirai, K., NozoE, S. \& Tsuda, K. (1967). Tetrahedron Lett. 23, 2177-2179.

Kubo, I., Lee, Y. W., Pettei, M., Pilikiewicz, F. \& Nakanishi, K. (1976). J. Chem. Soc. Chem. Commun. pp. 1013-1014.

MA, W. C. \& KUBO, I. (1977). Entomol. Exp. Appl. 22, 107-112.

Motherwell, W. D. S. \& ClegG, W. (1978). PLUTO. Program for plotting molecular and crystal structures. Univ. of Cambridge, England.

SHELDRICK, G. M. (1976). SHELX76. Program for crystal structure determination. Univ. of Cambridge, England.

TAYlOR, R. \& Kennard, O. (1982). J. Am. Chem. Soc. 104, 5063-5070. 